\title{
Psychosocial Aspects of Work and Musculoskeletal Disorders in Nursing Workers
}

\author{
Tânia Solange Bosi de Souza Magnago ${ }^{1}$ \\ Marcia Tereza Luz Lisboa ${ }^{2}$ \\ Rosane Harter Griep ${ }^{3}$ \\ Ana Lúcia Cardoso Kirchhof ${ }^{4}$ \\ Laura de Azevedo Guido ${ }^{1}$
}

This study aimed to evaluate the association between psychological demands and control on work and the occurrence of musculoskeletal disorders among nursing workers. This cross-sectional study involved 491 nursing workers from a University hospital in Rio Grande do Sul. Brazilian versions of the Nordic Musculoskeletal Questionnaire and the Job Content Questionnaire were used. Among the participants, $96.3 \%$ reported some pain in any given part of the body last year, $73.1 \%$ in the last seven days and $65.8 \%$ reported difficulty in their daily routine. The chances of shoulder pain $(\mathrm{OR}=1.97 ; \mathrm{CI} 95 \%=1.07-3.64)$, in the thoracic spine $(\mathrm{OR}=1.83 ; \mathrm{CI} 95 \%=1.02-3.35)$ and in the ankles $(\mathrm{OR}=2.05 ; \mathrm{CI} 95 \%=1.05$ 4.02) were higher in the high work demand quadrant when compared to the low demand quadrant, after adjustments for potentially confusing factors Intervention measures in the organizational structure are needed, redefining demand levels and control at work.

Descriptors: Work; Nursing; Occupational Health; Cumulative Trauma Disorders; Occupational Diseases.

\footnotetext{
1 Ph.D. in Nursing, Faculty, Departamento de Enfermagem, Universidade Federal de Santa Maria, RS, Brazil. E-mail: tmagnago@terra.com.br. E-mail: Iguido@terra.com.br.

2 Ph.D. in Nursing, Faculty, Escola de Enfermagem Anna Nery, Universidade Federal do Rio de Janeiro, RJ, Brazil. E-mail: marcialis@terra.com.br.

${ }^{3}$ Ph.D. in Sciences, Researcher, Laboratório de Educação Saúde e Ambiente, Fundação Osvaldo Cruz, RJ, Brazil. E-mail: rohgriep@terra.com.br.

${ }^{4}$ Ph.D. in Nursing, Visiting Researcher, Universidade Federal do Paraná. Retired Professor, Universidade Federal de Santa Catarina, SC, Brazil. E-mail: kirchhof@terra.com.br.
}

Corresponding Author:

Tânia Solange Bosi de Souza Magnago Universidade Federal de Santa Maria Av. Roraima, 1000 - prédio 26 (CCS) Bairro Camobi 


\title{
Aspectos psicossociais do trabalho e distúrbio musculoesquelético em trabalhadores de enfermagem
}

Este estudo objetivou avaliar a associação entre demandas psicológicas e controle sobre o trabalho e a ocorrência de distúrbios musculoesqueléticos em trabalhadores de enfermagem. Trata-se de estudo transversal, envolvendo 491 trabalhadores de enfermagem de um hospital universitário do Rio Grande do Sul, Brasil. Utilizaramse versões brasileiras do Nordic Musculoskeletal Questionnaire e do Job Content Questionnaire. Dos participantes, 96,3\% referiram dor em alguma região do corpo no último ano, 73,1\% nos últimos sete dias e 65,8\% relataram dificuldade nas atividades diárias. As chances de dor nos ombros $(\mathrm{OR}=1,97$; IC95\%=1,07-3,64), na coluna torácica $(\mathrm{OR}=1,83$; IC95\%=1,02-3,35) e nos tornozelos (OR=2,05; IC95\%=1,05-4,02) foram maiores no quadrante de trabalho em alta exigência quando se comparou ao de baixa exigência, após ajuste por potenciais fatores de confusão. Faz-se necessária a adoção de medidas interventivas na estrutura organizacional, redimensionando os níveis de demanda e de controle no trabalho.

Descritores: Trabalho; Enfermagem; Saúde do Trabalhador; Transtornos Traumáticos Cumulativos; Doenças Profissionais.

\section{Aspectos psicosociales del trabajo y disturbio músculo-esquelético en trabajadores de enfermería}

\begin{abstract}
Este estudio tuvo evaluar la asociación entre demandas psicológicas y el control sobre el trabajo y la ocurrencia de disturbio músculo-esqueléticos en trabajadores de enfermería. Se trata de un estudio transversal, envolviendo 491 trabajadores de enfermería de un hospital universitario en Rio Grande del Sur, en Brasil. Se utilizaron las versiones brasileñas del Nordic Musculoskeletal Questionnaire e del Job Content Questionnaire. De los participantes, 96,3\% refirieron dolor en alguna región del cuerpo en el último año, $73,1 \%$ en los últimos siete días y $65,8 \%$ relataron dificultades en las actividades diarias. Las probabilidades de dolor fueron: en los hombros (OR=1,97; IC95\%=1,07$3,64)$, en la columna torácica $(O R=1,83$; IC95\%=1,02-3,35) y en los tobillos $(O R=2,05$; IC95\%=1,05-4,02); fueron mayores en el cuadrante de trabajo con alta exigencia si comparado al de baja exigencia, después del ajuste por potenciales factores de confusión. Es necesario adoptar medidas de intervención en la estructura organizacional, redimensionando los niveles de demanda y de control en el trabajo.

Descriptores: Trabajo; Enfermería; Salud Laboral; Trastornos de Traumas Acumulados; Enfermedades Profissionales.
\end{abstract}

\section{Introduction}

In recent decades, studies ${ }^{(1-2)}$ with different methodological approaches have evidenced the relations between work, stress and their repercussions for workers' health. These have addressed issues like productivity, occupational accidents, absenteeism and increasing physical and mental symptom levels among workers in certain professional categories. Among professional categories, health workers stand out, particularly those working in the hospital environment, in view of the countless exhausting circumstances in their daily work environment.

The unhealthiness or burden of hospital work results from permanent exposure to one or more factors that produce diseases or suffering, deriving from the 
nature of work itself and its organization, as evidenced by non-specific and psychic signs and symptoms(2). Among health workers, research ${ }^{(1,3-4)}$ appoints nursing as one of the occupations with high risks for exhaustion and illness. The hospital environment can cause stress and physical problems among these workers, as work demands arise in this place, in which professionals experience different degrees of control over the activities they perform ${ }^{(1)}$.

Among occupational illnesses, musculoskeletal disorders (MSD) are an important public health problem and one of the most severe conditions in occupational health(5). The main risk factors include: work organization, environmental factors and possible overload on body segments when making certain movements, for example: excessive force to perform some tasks, repetitiveness and inadequate postures(6).

To understand these disorders, besides ergonomics issues, the psychosocial dimensions of the labor context are being analyzed, mainly in Europe, based on a model proposed at the end of the 1970's(3,7-8). That is the twodimensional Demand-Control Model - DCM. In the DCM, it is considered that exhaustion at work is produced by the interaction between high psychological demands and workers' low control over their job activities(1). Control over work covers issues related to skill use (learning new things, repetitiveness, creativity) and decision authority (ability to make decisions about one's own work, influence in the work group and in management policy) and psychological demand refers to the psychological requirements workers face while performing their tasks (time pressure, concentration level demanded while performing activities, task interruption and need to await activities performed by other workers) $)^{(1)}$.

In the DCM, four basic types of work experiences exist, constituted by the interaction between psychological demand and control levels: high strain (high demand and low control), low strain (low demand and high control), passive work (low demand and low control) and active work (high demand and high control) (1). Among the four situations, high strain is most strongly inclined towards physical and psychological illness work. Active and passive work represent intermediary illness risk, while low strain work represents the lowest risk and is considered the ideal work condition.

Considering the lack of Brazilian knowledge production about the theme proposed in this paper(6), this research aims to assess the association between psychological demands and control over work and the occurrence of MSD among nursing workers at a University Hospital in Rio Grande do Sul, Brazil. In this context, the study problem is the relation between psychological demands, workers' control and MSD development.

\section{Methods}

Approval for this cross-sectional study was obtained from the Research Ethics Committee at Universidade Federal de Santa Maria - UFSM/RS (Opinion No 23081.000398/2006-10). All 528 nursing workers hired through a public examination and working at the University Hospital under analysis were defined as eligible. Nine trained nursing students collected data between March and September 2006. Interviews with the workers took placed at a private place during work times. Workers on medical leave were interviewed at home after previous contact by telephone.

Exposure to the psychosocial dimensions of work (independent variable) was assessed through the Job Content Questionnaire - JCQ, translated and adapted to Portuguese ${ }^{(9)}$ and available from http://www. jcqcenter.org. Five questions were used to assess the psychological demand and nine for control over work. Four answer options were presented for the demand and control dimensions: "strongly disagree, disagree, agree and strongly agree". To compose the DCM groups, the criteria recommended in the JCQ manual were used. To dichotomize the demand and control variables, the median was used as the cut-off point. Based on these two dimensions, dichotomized into high and low, the four categories were set up: low strain, active work, passive work and high strain. Cronbach's Alpha coefficients for psychological demand and control corresponded to 0.70 and 0.59 , respectively.

The outcome - MSD (dependent variable) - was assessed by means of the Brazilian version of the Standardized Nordic Questionnaire(10). MSD patients were defined as workers who positively answered the question: "Have you experienced some pain or discomfort in your...(neck, shoulders, elbows, wrist or hand, thoracic spine, lumbar column, thighs, legs, knees and ankles) during the last year?"

Other characteristics were analyzed: a) sociodemographic variables: gender (female; male); age (22 to 38 years; 39 to 46 years and more than 47 years); education (graduated and not graduated); marital situation (single, no partner and married, with partner); children under six years of age (yes; no); 
Body Mass Index - BMI (eutrophic; overweight and obese); smoking (does not smoke; smokes and used to smoke but stopped) and per capita family income in minimum wages (less than 2 wages; 2 to 3 wages and more than 3 wages), b) job variables: function (nurse; nurse technician or auxiliary); time on the job and in the sector; sector; shift (day and night); weekly hour load (30h; 36 and 40h); other job (yes; no) and physical strain at work (high; low).

Data were processed using Epi-info ${ }^{\circledR}$ software, version 6.0, through independent double entry. After checking for errors and inconsistencies, data were analyzed in SPSS $^{\circledR} 13.0$ for Windows. Univariate and bivariate analyses were performed to verify the association between exposure and outcome with each of the co-variables under analysis. The chi-square test was used to verify whether the identified associations were statistically significant ( $p<0.05$ ). To select possible confounding variables, $p<0.10$ was adopted, and variables associated with both exposure and outcome were included in the multivariate models. Analyses adjusted for confounding factors were performed in two steps and separately for each body region: Model 1: association between the DCM quadrants and the MSD adjusted for socioeconomic and work-related covariables and Model 2: adding the co-variable physical strains to Model 1.

Participants whose activities were classified as high strain, passive work and active work were compared to others allocated in the low strain category. Association was measured through the Odds Ratio (OR) and its respective confidence intervals (CI95\%).

\section{Results}

Characterization of the population: 491 (93\%) eligible workers participated in the research. Women predominated $(88.4 \%)$; the majority (36.7\%) was between 22 and 38 years old; was married or lived with a partner $(65.8 \%) ; 21.2 \%$ had children under six years of age; $41.3 \%$ have a per capita family income of less than two minimum wages; $48 \%$ were overweight and $10.8 \%$ were smokers. As to category, $29.7 \%$ were nurses, $32.8 \%$ nurse technicians and $37.5 \%$ nurse auxiliaries. Their average time on the job was 14.4 years $( \pm 8.3)$ and in the current sector eight years $( \pm 6.6)$. The majority $(59.3 \%)$ worked day shifts; (53\%) worked 36 hours per week and a minority (26.3\%) mentioned another job contract.

Characterization of the MSD: the global prevalence of pain or musculoskeletal discomfort among nursing workers during the study period was $96.3 \%$ in the last 12 months and $73.1 \%$ in the last seven days. In the past year, pain or discomfort was more frequent in the following regions: lumbar (71.5\%), neck (68\%), shoulders $(62.2 \%)$ and legs $(54.6 \%)$. The pain and discomfort that most impaired their daily work were located in the following regions: lumbar (60.4\%), wrists and hands (58\%), thoracic spine $(54.7 \%)$ and elbows $(54.1 \%)$. In the last seven days, pain or discomfort were mentioned in the lumbar column (56.4\%), legs (49.6\%) and neck (47.9\%).

Characterization of DCM quadrants: among younger workers and workers who were married or lived with a partner, higher frequencies were found in the active work and high strain categories. Among non-graduated workers, passive work and high strain frequencies were higher among those with the lowest family income per capita and smokers. Low strain and active work were more frequent among nurses. Workers with less time on the job and in the sector stood out in the active work and high strain quadrants. The predominance of these same quadrants was identified among Emergency Unit workers. High frequencies of passive work and high strain were present at the Surgical Unit. The Outpatient and Maternal-Infant Units showed high frequencies of passive work.

Among day shift workers, the active work quadrant predominated, against passive work and high strain among night shift workers. The low strain and active work quadrants predominated among workers who mentioned another job when compared to those who do not have another job. Physical strain was associated with higher predominance of active work and high strain.

Table 1 displays the results of gross and adjusted analyses between the DCM quadrants and the places where pain or musculoskeletal discomfort were mentioned.

In Table 1, the adjusted analyses between the DCM quadrants and the prevalence of MSD in different body regions evidence greater chance of MSD in the shoulders $(\mathrm{OR}=1.97 ; \mathrm{CI} 95 \%=1.07-3.64)$, thoracic spine $(\mathrm{OR}=1.83 ; \mathrm{CI} 95 \%=1.02-3.35)$ and ankles $(\mathrm{OR}=2.05 ; \mathrm{CI} 95 \%=1.05-4.02)$ among high strain workers than among low strain workers. In the gross association, on the other hand, this association is lost among workers in this quadrant with higher chances of neck, lumbar column and leg pain when adjusted for potential confounding variables. 
Table 1 - Gross and adjusted associations between quadrants of the Demand-Control model and musculoskeletal disorders, according to affected body regions, HUSM. Santa Maria, RS, 2006. $(n=491)$

\begin{tabular}{|c|c|c|c|c|}
\hline \multicolumn{5}{|c|}{ Gross Association** } \\
\hline Body area * & LD & PW OR (CI) & AW OR (CI) & HD OR (CI) \\
\hline Neck & 1.00 & $0.83(0.49-1.40)$ & $1.51(0.87-2.62)$ & $1.87(1.02-3.46)$ \\
\hline Shoulders & 1.00 & $1.23(0.74-2.05)$ & $1.95(1.15-3.31)$ & $2.39(1.33-4.27)$ \\
\hline Thoracic Spine & 1.00 & $1.23(0.73-2.08)$ & $1.65(0.97-2.80)$ & $2.43(1.38-4.29)$ \\
\hline Lumbar Column & 1.00 & $1.78(1.04-3.06)$ & $2.00(1.15-3.48)$ & $2.11(1.15-3.85)$ \\
\hline Legs & 1.00 & $0.99(0.60-1.66)$ & $1.74(1.04-2.93)$ & $2.04(1.16-3.58)$ \\
\hline Ankles & 1.00 & $2.04(1.12-3.71)$ & $1.44(0.77-2.67)$ & $2.31(1.23-4.35)$ \\
\hline \multicolumn{5}{|c|}{ Adjusted Association - Model $1^{\star \star *}$} \\
\hline Body area * & LD & PW OR (Cl) & AW OR (CI) & HD OR (Cl) \\
\hline Neck & 1.00 & $0.90(0.53-1.54)$ & $1.44(0.82-2.53)$ & $1.77(0.95-3.29)$ \\
\hline Shoulders & 1.00 & $1.30(0.77-2.19)$ & $2.02(1.18-3.45)$ & $2.39(1.33-4.31)$ \\
\hline Thoracic Spine & 1.00 & $1.13(0.65-1.96)$ & $1.80(1.04-3.10)$ & $2.10(1.17-3.76)$ \\
\hline Lumbar Column & 1.00 & $1.86(1.06-3.25)$ & $2.06(1.17-3.62)$ & $1.90(1.03-3.50)$ \\
\hline Legs & 1.00 & $1.18(0.70-2.00)$ & $1.72(1.01-2.92)$ & $1.89(1.07-3.36)$ \\
\hline Ankles & 1.00 & $1.74(0.94-3.20)$ & $1.52(0.77-2.76)$ & $2.22(1.16-4.24)$ \\
\hline \multicolumn{5}{|c|}{ Adjusted Association - Model $2^{\star * \star *}$} \\
\hline Body area * & LD & PW OR (Cl) & AW OR (Cl) & HD OR (Cl) \\
\hline Neck & 1.00 & $0.92(0.54-1.58)$ & $1.22(0.68-2.18)$ & $1.43(0.75-2.73)$ \\
\hline Shoulders & 1.00 & $1.34(0.79-2.26)$ & $1.72(0.99-2.99)$ & $1.97(1.07-1.64)$ \\
\hline Thoracic Spine & 1.00 & $1.16(0.67-2.02)$ & $1.57(0.89-2.77)$ & $1.83(1.02-3.35)$ \\
\hline Lumbar Column & 1.00 & $1.98(1.13-3.50)$ & $1.56(0.87-2.83)$ & $1.36(0.72-2.60)$ \\
\hline Legs & 1.00 & $1.22(0.72-2.08)$ & $1.43(0.82-2.48)$ & $1.51(0.83-2.76)$ \\
\hline Ankles & 1.00 & $1.77(0.96-3.27)$ & $1.41(0.73-2.71)$ & $2.05(1.05-4.02)$ \\
\hline
\end{tabular}

Legend: LD (low demand - reference category), PW (passive work), AW (active work), HD (high demand), OR (odds ratio), CI (confidence interval).

* The elbow, hand and wrist, thigh and knee regions were not included in Table 1 due to non-significant values ( $p>0.05$ ). Significant variables for exposure and outcome (confounding factors): Neck: Age, smoking, time on the job, sector and physical demand. Shoulder: Smoking, sector and physical demand. Thoracic spine: Education level, smoking, family income per capita, function, sector and physical demand. Lumbar column: Education level, sector and physical demand. Ankles: Family income per capita, time in the sector, work shift and weekly hour load;

** Gross association = demand-control groups;

*** Model 1 = demand-control groups + significant co-variables for each body region, except physical demand;

**** Model 2 = demand-control groups + co-variables of adjusted association $1+$ physical demand.

Table 1 also demonstrates that, among workers in the active work quadrant, the higher chances of pain in the shoulder, thoracic spine, lumbar column and leg regions identified in the gross association and in adjusted association 1 lose association when adjusted for physical strain.

Finally, data in Table 1 represent chances of lumbar column pain twice as high among workers in the passive work quadrant than in the low strain quadrant, even after adjusting for age, education level, sector and physical strain. The association found for ankle pain among workers in this quadrant was lost when adjusted for age, family income per capita, time in the sector, work shift, weekly hour load and physical strain.

\section{Discussion}

These study results appoint that workers submitted to high strain in the work environment have greater chances of developing musculoskeletal pain in some body regions than those classified as low demand. Psychosocial variables (psychological demand and control) were more associated with pain in central regions (shoulders, thoracic spine and lumbar column) than in peripheral regions (upper and lower limbs), in line with other studies ${ }^{(3,7,11)}$. These results are coherent with others ${ }^{(1,12)}$ showing that stress is one of the routes through which the psychosocial environment affects bone and muscle health, supposedly through muscle tension. Physiologically(13), emotional tension causes spasms in different muscles, particularly in the cervica region (trapezium and levator scapulae), resulting in pain episodes.

The accelerated work rhythm due to the activity overload (staff deficit, number and severity of patients) is another aggravating factor and can make nursing workers adopt inadequate postures (bathing, venipuncture and dressings), which represents a risk 
factor for pain in central regions. To give an example, maintaining the shoulder in abduction can provoke partial ischemia in the vessels that irrigate the tendons, among other components. When this situation continues, micro-injuries occur in the muscles and tendons. The lack of irrigation makes it difficult for these injuries to heal, resulting in pain(14).

In line with the hypothesis about this relation, in a study with salesmen(11), an association was found between high strain and neck pain. In a research among professionals from different $\operatorname{areas}^{(7)}$, sixty-percent higher prevalence levels were found for central region than for peripheral region pain among workers in the high strain group. There is evidence that workers submitted to high strain situations present high stress hormone (cortisol and adrenaline) production and release levels ${ }^{(9)}$. Too high levels of these hormones cause damage to the musculoskeletal system due to the edema and nerve compression caused by the high cortisol levels and the circulation decrease caused by adrenaline ${ }^{(14)}$.

These are probable signs of the relation between psychosocial aspects and MSD. However, studies do not agree about the most affected body regions. In a systematic review, the authors ${ }^{(15)}$ evidenced an association between at least one psychosocial factor and musculoskeletal systems in upper extremities (shoulders, elbows, wrists and hands). In this study, it was observed that the level of demand nursing workers are submitted to increased the chance of self-referred musculoskeletal symptoms in some body regions. In other words, the chance of developing shoulder pain was twice as high among workers classified in the high strain group when compared with the low strain group, even after adjusting for smoking, work sector and physical strain. Likewise, it was observed that the change of referring thoracic spine pain was $83 \%$ higher among high strain than among low strain workers, even after adjustments for education level, smoking, per capita family income, function, sector and physical strain (Table 1).

With regard to the psychosocial aspects of work, various components of nursing work interfere in these workers' health, among which the following stand out: time pressure(16); state of alertness; task fragmentation; administrative, environmental and relationship issues ${ }^{(17)}$. Factors like competitiveness, low autonomy, invariability of activities, insecurity at work, lack of support (colleagues and heads) and feeling overloaded would also be related to increased MSD among workers ${ }^{(11)}$.

These findings indicate that not only frequent mechanic exposure, butalso organizational, psychological and social aspects can represent risk factors for musculoskeletal complaints in nursing workers. These situations favor tensions and contribute to increase fatigue and job stress experiences. These often decisively converge to the occurrence of diseases with multiple etiological factors, like in the case of $\mathrm{MSD}^{(4)}$.

Although the psychosocial aspects of work cannot directly be related as causes of MSD based on the present study results (limitation inherent in crosssectional studies), three possible association routes are presented in literature ${ }^{(12)}$, which can also make sense for nursing work:

1 - effect on the physical burden: through the large volume of activities, staff deficit and large patient quantities. Time pressure would act on workers as psychological pressure and would make them perform movements faster and adopt inadequate postures during activities;

2 - lead to stress: constant contact with pain and death; the conflicting demands of work (need to interrupt one activity to perform another, do it fast and be at risk of an accident or a mistake...); responsibilities for care and patient safety; conflicting relations inside the team itself or with another team; lack of recognition; problems with equipment and materials, inadequate work stations, among others, are daily situations in nursing work. Working in inadequate conditions, with environmental, equipment and process problems, can result in exhaustion and increased muscle contraction. In the long term, this situation can lead to the development or exacerbation of MSD through a physiological and possibly hormonal mechanism(12). This assertion is supported by other

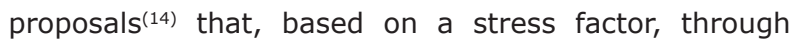
the central or autonomous nervous system, a series of physiological reactions occur that make a person manifest musculoskeletal symptoms and,

3 - in pain sensitivity: daily coping with these situations at work would decrease workers' pain perception threshold, resulting in increasingly frequent reports about musculoskeletal symptoms.

These results add up to others already published in this journal about the theme under analysis(5,18-19) and contribute to the identification of a positive association between psychosocial aspects of work and MSD, with three body regions susceptible to this type of exposure. Further research using this method is needed to confirm the consistency of the identified associations.

In sum, the nursing work conditions observed in this and other studies reviewed converge towards the 
assertion that the hospital environment imposes harmful exhaustion, entailing consequences for workers' bone and muscle health(19). In conclusion, the prevention of MSD involves understanding the psychosocial and stress factors in the work environment. This understanding can help to develop health promotion and MSD prevention strategies in this worker class, such as: making better use of technologies to perform work demanding greater physical strength, adopting sporadic breaks during the work shift, improve the organizational climate through good governance of different position inside and between teams.

\section{Acknowledgements}

Acknowledgements to Tânia Araújo and Márcia Guimarães de Mello Alves for their constant help to understand the Demand-Control Model; to the interviewers Juliana Petri Tavares, Francine Cassol Prestes, Lucilene Gama Paes, Carolina Nonnenmacher, Letícia Vieira, Lílian Stekel and Raquel Kirchhof; to CAPES for financial support -PQI/UFSM/UFRJ grant.

\section{References}

1. Karasek RA, Theörell T. Healthy work-stress, productivity, and the reconstruction of working life. New York: Basic Books; 1990.

2. Dejours C. A loucura do trabalho: estudo da psicopatologia do trabalho. 5 ed. São Paulo (SP): Cortez; 1992.

3. Josephson M, Lagerström M, Hagberg M, Hjelm EW. Musculoskeletal symptoms and job strain among nursing personnel: a study over a three year period. Ocup Environ Med 1997 july; 54(9):681-5.

4. Menzel NN. Psychosocial factors in musculoskeletal disorders. Crit Care Nurs Clin Am 2007 june; 19(2): 145-53.

5. Gurgueira GP, Alexandre NMC, Correa HR Filho. Prevalência de sintomas músculo-esqueléticos em trabalhadores de enfermagem. Rev Latino-am Enfermagem 2003 setembro-outubro; 11(5):608-13.

6. Magnago TSBS, Lisboa MTL, Griep RH. Trabalho da enfermagem e distúrbio musculoesquelético: revisão das pesquisas sobre o tema. Esc Anna Nery 2008 setembro; 12(3):560-5.

7. Toomingas A, Theörell $T$, Michesen $H$, Nordemar R. Associations between self-rated and psychosocial work conditions and musculoskeletal symptoms and signs. Scand J Work Environ Health 1997 April; 23(2):130-9.

8. Feng C-K, Chen M-L, Mao I-F. Prevalence of risk factors for different measures of low back pain among female nursing aides in Taiwanese nursing homes. [on line]. 2007. [acesso 28 junho 2008]. Disponível em: http:// www.biomedcentral.com/1471-274/8/52.

9. Araújo TM, Graça CC, Araújo E. Estresse ocupacional e saúde: contribuições do modelo demanda-controle. Ciênc Saúde Coletiva 2003; 8(4):991-1003.
10. Barros ENC, Alexandre NMC. Cross-cultural adaptation of Nordic musculoskeletal questionnaire. Int Nurs Rev 2003 June; 50(2):101-8.

11. Skov T, Borg V, Orhede E. Psychosocial and physical risk factors for musculoskeletal disorders of the neck, shoulders, and lower back in salespeople. Occup Environ Med. 1996 May; 53(5):351-6.

12. Bongers PM, Winter CR, Kompier M, Hilderbrandt V. Psychosocial factors at work and musculoskeletal disease. Scand J Work Environ Health 1993 October; 19(5):297-312.

13. Guyton AC. Neurociência básica: anatomia e fisiologia. 2 ed. Rio de Janeiro (RJ): Guanabara Koogan; 1993.

14. Aptel MO, Cnockaert JM. Stress and work related musculoskeletal disorders of the upper extremities. France: Tutb Newletter 2002 September; (19-20):50-6. 15. Bongers PM, Kremer AM, Laak JT. Are psychosocial factors, risk factors for symptoms and signs of the shoulder, elbow, or hand/wrist?: a review of the epidemiological literature. Am J Ind Med. 2002 May; 41(5):315-42.

16. Costa ALRC, Marziale MHP. Relação tempo-violência no trabalho de enfermagem em emergência e urgência. Rev Bras Enferm 2006 maio-junho; 59(3):337-43.

17. Beck CLC. O sofrimento do trabalhador: da banalização a re-significação ética na organização da enfermagem. Florianópolis (SC): UFSC; 2001.

18. Leite $P C$, Merighi MAB, Silva A. A vivência de uma trabalhadora de enfermagem portadora de lesão "De Quervain". Rev. Latino-Am. Enfermagem. 2007 marçoabril;15(2):253-8.

19. Murofuse NT, Marziale MHP. Doenças do sistema osteomuscular em trabalhadores de enfermagem. Rev. Latino-Am. Enfermagem. 2005 maio-junho; 13(3):364-73.

Received: Apr. $27^{\text {th }} 2009$

Accepted: Oct. $6^{\text {th }} 2009$ 